University of Nebraska - Lincoln

DigitalCommons@University of Nebraska - Lincoln

1996

\title{
Survival of Radiomarked Canvasback Ducklings in Northwestern Minnesota
}

\author{
Carl E. Korschgen \\ Upper Mississippi Science Center \\ Kevin P. Kenow \\ Upper Mississippi Science Center \\ William L. Green \\ Upper Mississippi Science Center \\ Douglas H. Johnson \\ USGS Northern Prairie Wildlife Research Center, Douglas_H_Johnson@usgs.gov \\ Michael D. Samuel \\ National Wildlife Health Center \\ See next page for additional authors
}

Follow this and additional works at: https://digitalcommons.unl.edu/usgsnpwrc

Part of the Other International and Area Studies Commons

Korschgen, Carl E.; Kenow, Kevin P.; Green, William L.; Johnson, Douglas H.; Samuel, Michael D.; and Sileo, Louis, "Survival of Radiomarked Canvasback Ducklings in Northwestern Minnesota" (1996). USGS Northern Prairie Wildlife Research Center. 222.

https://digitalcommons.unl.edu/usgsnpwrc/222

This Article is brought to you for free and open access by the US Geological Survey at DigitalCommons@University of Nebraska - Lincoln. It has been accepted for inclusion in USGS Northern Prairie Wildlife Research Center by an authorized administrator of DigitalCommons@University of Nebraska - Lincoln. 


\section{Authors}

Carl E. Korschgen, Kevin P. Kenow, William L. Green, Douglas H. Johnson, Michael D. Samuel, and Louis Sileo 


\title{
SURVIVAL OF RADIOMARKED CANVASBACK DUCKLINGS IN NORTHWESTERN MINNESOTA
}

\author{
CARL E. KORSCHGEN, National Biological Service, Upper Mississippi Science Center, P. O. Box 818, La Crosse, WI 54602- \\ 0818, USA \\ KEVIN P. KENOW, National Biological Service, Upper Mississippi Science Center, P. O. Box 818, La Crosse, WI 54602-0818, \\ USA \\ WILLIAM L. GREEN, National Biological Service, Upper Mississippi Science Center, P. O. Box 818, La Crosse, WI 54602-0818, \\ USA \\ DOUGLAS H. JOHNSON, National Biological Service, Northern Prairie Science Center, 871137 Street Southeast, Jamestown, \\ ND 58401, USA \\ MICHAEL D. SAMUEL, National Biological Service, National Wildlife Health Center, 6006 Schroeder Rd., Madison, WI 53711, \\ USA \\ LOUIS SILEO, National Biological Service, National Wildlife Health Center, 6006 Schroeder Rd., Madison, WI 53711, USA
}

Abstract: Duckling survival, an important factor affecting annual recruitment, has not been determined adequately for canvasbacks (Aythya valisineria). We investigated the magnitude, timing, and causes of mortality of canvasback ducklings from hatch to fledging at the Agassiz National Wildlife Refuge (NWR) in northwestern Minnesota during 1987-90. During the 4 years, 217 day-old ducklings were radiomarked and released in 52 broods. Another 141 ducklings were radiomarked at $\geq 4$ weeks of age. Survival was estimated with the Kaplan-Meier nonparametric estimator and the Weibull parametric model. Most mortalities occurred within 10 days after hatch. Total brood loss occurred in $18(35 \%)$ of 52 broods released. The primary sources of mortality were predation, principally by mink (Mustela vison), and exposure to precipitation and cold temperature. For combined years, females had lower survival than males $(P=0.03)$. If the disparate survival between sexes of canvasbacks observed in this study is representative of canvasbacks in their breeding range, this phenomenon contributes to reduced reproductive potential and the male-biased sex ratio of the species.

J. WILDL. MANAGE. 60(1):120-132

Key words: Agassiz National Wildlife Refuge, Aythya valisineria, canvasback, duckling survival, mortality, radiotelemetry, survival analysis.

Between 1981 and 1994, the continental breeding population of canvasbacks (Can. Wildl. Serv. and U.S. Fish and Wildl. Serv. 1994) had not attained the management goal of 580,000 that was established for the North American Waterfowl Management Plan (U.S. Fish and Wildl. Serv. and Can. Wildl. Serv. 1986). Because of concern over reduced population levels, the U.S. Fish and Wildlife Service listed the canvasback as a species of special emphasis. Restrictive hunting regulations to limit canvasback harvest have been in effect periodically since 1972. However, effective management cannot be implemented without a better understanding of recruitment and causes of mortality in this species.

Duckling survival can be an important factor affecting annual recruitment (Cowardin and Johnson 1979, Cowardin et al. 1985, Orthmeyer and Ball 1990) but is probably the least understood component of waterfowl demographics (Ball et al. 1975, Cowardin et al. 1985). Survival rates and causes of mortality of canvasback ducklings have been difficult to determine because broods are secretive, loss of entire broods may go unaccounted for, and brood intermixing occurs as brood bonds weaken with age (Stoudt 1982, Leonard 1990). Failure to account for losses of entire broods, for example, may lead to overestimation of survival (Ball et al. 1975, Reed 1975, Ringelman and Longcore 1982, Talent et al. 1983). Our objectives were to determine the magnitude, timing, and causes of canvasback duckling mortality using innovative radiotelemetry techniques.

The assistance of B. M. Ballard, L. A. Bennett, P. J. Boma, A. F. Boysen, J. P. Cowardin, J. M. Coffey, M. D. Havlik, D. C. Hurt, J. J. Jansen, T. G. Maeder, D. F. Miller, L. C. Mueller, B. R. Paulson, R. D. Pritchert, D. R. Spuhler, B. D. Woodsen, and G. D. Zenitsky was greatly appreciated. The staff of the Agassiz National Wildlife Refuge, especially V. D. Erickson, J. Kotok, J. P. Mattsson, G. D. Tischer, and B. J. Wickstrom supported our study. We are grateful to T. L. Shaffer for statistical advice. We 
thank C. J. Brand, F. J. Dein, D. R. Goldberg, and $\mathrm{J}$. Langenberg for veterinary, pathology, and diagnostic assistance. We also thank J. R. Cary for assistance with software development, W. E. Dodge for making telemetry program XYLOG available, C. R. Luna for consultation on radiotransmitter attachment, and $M$. D. Schwartz for programming support. F. W. Anderka developed miniature radiotransmitters for day-old ducklings. We appreciate the critical review of this manuscript provided by J. E. Austin, G. M. Haramis, W. L. Hohman, W. E. Newton, and P. J. Pietz.

\section{STUDY AREA}

The Agassiz NWR is in the ecotone of the prairie and northern forest ecosystems in northwestern Minnesota. The refuge occupied 24,878 ha in a remnant depression of glacial Lake Agassiz. The topography was relatively flat, and drainage of the area was slow. Construction of dikes and watercontrol structures since 1937 had formed 18 separate impoundments, which ranged from 75 to 4,000 ha. The average maximum water depth of impoundments ranged from 0.7 to $1.3 \mathrm{~m}$. The wetland area on the refuge totaled 15,748 ha.

Impoundments were categorized as persistent emergent and aquatic-bed wetlands (Cowardin et al. 1979). Emergent vegetation was predominantly common cattail (Typha latifolia), narrowleaf cattail ( $T$. angustifolia), softstem bulrush (Scirpus validus), tule bulrush (S. acutus), common reed (Phragmites communis), sedges (Carex spp.), and giant burreed (Sparganium eurycarpum). Submersed vegetation included fennelleaf pondweed (Potamogeton pectinatus), baby pondweed (P. pusillus), common hornwort (Ceratophyllum demersum), common bladderwort (Utricularia vulgaris), and spiked watermilfoil (Myriophyllum exalbescens).

Waterfowl production and quality habitat to support waterfowl use are the primary objectives of the Agassiz NWR. In recent years, management at the Agassiz NWR has emphasized increased production of overwater-nesting waterfowl. It was the only refuge in the midwestern United States with consistent canvasback production during 1954-74 (W. E. Green, U.S. Fish and Wildl. Serv., pers. commun.). During this 21-year period, the average annual use-days of canvasbacks was 46,293 , and an average of 477 young were produced each year. The av- erage number of canvasback breeding pairs during 1973-82 was $183 \pm 133$ (SD) pairs; an estimated 920 canvasbacks were produced at the refuge in 1982 (C. D. Swanberg, U.S. Fish and Wildl. Serv., pers. commun.).

\section{METHODS \\ Nest Searching}

With an airboat, we found canvasback nests in May and June by systematically searching suitable emergent vegetation. We thoroughly searched locations where we saw canvasback females. To reduce airboat disturbance and to increase search efficiency, we also located nests by observing the movements of radiomarked canvasback females. We captured females with decoy (Anderson et al. 1980) or bait (Haramis et al. 1987) traps, and implanted radiotransmitters in the birds' abdominal cavities (Korschgen et al. 1984, Olsen et al. 1992) or subcutaneously on their backs (Korschgen et al. 1996). We monitored the birds with standard telemetry techniques.

\section{Collection and Incubation of Eggs}

During 1987, eggs were removed from canvasback nests regardless of stage of incubation and placed in an incubator for hatching. In later years, however, we allowed the female to incubate the eggs for $>10$ days to achieve greater hatching success and synchronization of hatching (see Doty 1972). In their place we substituted water-filled plastic eggs, painted to match the color of canvasback eggs, or redhead (Aythya americana) eggs in a less advanced stage of development. To synchronize hatching, we incubated all eggs from each brood in physical proximity.

\section{Radiomarking Ducklings}

We used a clutch (set of eggs from the same nest) of $\geq 4$ eggs that hatched within 12 hours as an experimental brood. When a clutch hatched, we determined body mass and sex for each duckling and we randomly assigned ducklings to be radiomarked. We also chose at random the order of radiomarking. We attempted to radiomark about $75 \%$ of ducklings in each brood. We also collected cloacal and tracheal swab samples from ducklings during the 1990 field season as part of disease monitoring by the National Wildlife Health Center (NWHC), Madison, Wisconsin (see Goldberg et al. 1995). We implanted miniature radiotransmitters 
subcutaneously between the scapulars of ducklings within hours after hatch. Handling and care of ducklings and surgical techniques (Korschgen et al. 1996) were approved by the Animal Care and Use Committee of the Northern Prairie Science Center, and comply with the Animal Welfare Act (Public Law 99-198 and 9 CFR Parts 1, 2, and 3). We performed surgery under as aseptic conditions as possible with the general anesthetic, isoflurane. We used crystal-controlled, 2-stage pulse, internally implantable radiotransmitters (model BD-2TI, Holohil Systems, Ltd., Woodlawn, Ont., Canada K0A 3M0; use of manufacturer's name does not imply government endorsement). Transmitters were encapsulated in Scotchcast electrical resin 215 (3M Co., St. Paul, Minn.). The transmitters were rectangular, measured about $20 \times 9 \times 5.5$ $\mathrm{mm}$, weighed about $1.8 \mathrm{~g}$, and had a life expectancy of 35 days. The antenna was a 170$\mathrm{mm}$ twisted (multi-strand) stainless-steel wire coated with black nylon that exited the duckling's skin through a formed opening. The pulse rate of the transmitter was thermistor-regulated for remote monitoring of duckling body temperature. This device also served as a mortality cue.

\section{Duckling Release}

Before releasing ducklings, we placed 1-2 pipping eggs in experimental nests to stimulate the hen with sound and movement of hatching. Ducklings were released $<12$ hours after hatch to enhance imprinting on the foster nesting female. To restrain ducklings on the nest until the nesting female returned, we placed the ducklings in a paper envelope made of hand towels. We stapled the top of the envelope closed and covered it with nest material. After a period of time the ducklings easily ripped open the paper envelope, especially after the envelope had been wetted by moisture from the nest bowl or the returning nesting female. With video cameras at $22 \%(n=53)$ of the nest sites, we confirmed that nesting females accepted broods released in this manner.

\section{Radiotracking}

We attempted to locate and determine transmitter temperatures of all radiomarked ducklings several times daily from vehicles, boats, or aircraft. We processed telemetry azimuth data in the field with portable personal computers and the program XYLOGAGZ (Kenow et al.,
Natl. Biol. Serv., unpubl. software), a modified version of XYLOG4 (Dodge and Steiner 1986). The program also was used to immediately calculate and display transmitter temperature and thereby determine live or dead status. Because transmitters in day-old ducklings had a limited life, we used nightlighting techniques (Cummings and Hewitt 1964) to recapture radiomarked ducklings and replace expiring transmitters with larger transmitters $(28 \times 13 \times 6$ $\mathrm{mm}, 4.0 \mathrm{~g}$ ) that had greater radiated power and longer life. We removed expiring transmitters and subcutaneously implanted new transmitters in a single surgical procedure. Unmarked ducklings ( $\geq 4$ weeks of age) were also captured by nightlighting and were radiomarked. All ducklings were returned to the site of capture. If the hatch date of the duckling was unknown, we determined age by plumage development (Dzubin 1959, Weller 1957).

\section{Determination of Cause of Death}

Dead birds were recovered as quickly as possible. If radiomarked broodmates were in the same area as the dead duckling, we delayed recovery until telemetry locations indicated that the brood had left the area. In most predatorrelated mortalities, little of the carcass remained. Predator identification was based on recovery location of carcass or transmitter (e.g., in a mink den, underneath a raptor perch), and evidence on carcass or transmitter. When cause of death was undetermined in 1988 and 1989 , carcasses were frozen for later necropsy at the NWHC. During 1990, fresh carcasses were shipped to NWHC for immediate necropsy. All carcasses examined at NWHC received a complete pathological examination including selected diagnostic and histopathology studies to evaluate viruses, bacteria, and parasites. A sample of carcasses was tested for organophosphorus and carbamate exposure based on brain acetylcholinesterase activity (Hill 1988, Rocke and Samuel 1991). Determination of proximate and contributing causes of mortality was based on diagnostic findings in combination with field evidence, i.e., weather conditions, brood history, and movements.

We classified causes of mortality in 5 categories: predation, disease, weather-related, inanition (starvation), and unknown/other. Predation was considered a contributing cause of death when predation-like trauma was present at necropsy and field evidence suggested pre- 
dation, but cause of trauma was not certain. Disease-related mortality included pneumonia, parasitism, and other incidental health problems. We assessed weather conditions (daily temperature and rainfall) at the Agassiz NWR headquarters 48 hours before death for ducklings with no apparent cause of mortality. We considered weather a direct cause of death (exposure) of ducklings whose carcasses indicated good or fair body condition (primarily body fat deposits) when the proximate time of death coincided with rainfall or cold $(<11 \mathrm{C})$ temperature. We diagnosed inanition (Langenberg and Montali 1983) when the carcass was emaciated but otherwise normal. We listed the cause of death as unknown if the carcass revealed no clear pathological information, was too autolyzed for complete diagnostic procedures, or had signs of uncommon causes of death (e.g., drowning). In many cases, multiple factors probably contributed to the proximate cause of death.

Differences between ( $t$-tests) and among (analysis of variance) mean duckling body mass by sex, year, and cause of death were identified with SAS statistical software (SAS Inst. Inc. 1989).

\section{Survival Analysis}

We estimated survival rates of ducklings radiomarked at $<1$ day old and $\geq 4$ weeks old (Class II ducklings). Some birds were in both groups. Survival rates of the two groups were estimated separately.

In our analyses, we treated all ducklings as if they were statistically independent. In reality, ducklings of the same brood probably do not experience statistically independent fates but are exposed to similar predation, weather, and other risks. Treating ducklings as independent does not result in biased estimators of survival, but variance estimators are biased low (e.g., Pollock et al. 1989).

Day-old ducklings.-We initially used the nonparametric Kaplan-Meier approach (Kaplan and Meier 1958) to calculate survival rates of ducklings that were radiomarked at hatch. This method does not restrict the shape of the survival curves to a particular parametric model. We used the LIFETEST module in SAS (SAS Inst. Inc. 1989) for fitting Kaplan-Meier curves. Plots of $\log \{-\log [S(t)]\}$ against $\log ($ time $)$ obfrom the Kaplan-Meier procedure were generally linear, indicating that a Weibull survival model would adequately fit the data. The Kaplan-Meier method requires large samples to obtain precise survival estimates, but only about $39 \%$ of our ducklings survived past 10 days of age. (In fact, the Kaplan-Meier method is only about $60 \%$ efficient when applied to data from the Weibull distribution [Miller 1983]). We consequently used the Weibull model to further analyze survival data. We used the LIFEREG module of SAS (SAS Inst. Inc. 1989) to compute estimated parameters of the Weibull survival models.

The Weibull survival model was flexible enough to accommodate our data; the mortality rate was high among young birds and declined with age. In general, parametric models provide more precise estimates of survival if the model fits well (Miller 1983, Klein and Moeschberger 1989), as did our data. For the Weibull distribution, the survival function, which describes the probability of survival as a function of age $(t)$, is $S(t)=\exp \left(-\alpha t^{\gamma}\right)$. The hazard rate, which describes the instantaneous death rate, decreases with age if $\gamma<1$. The LIFEREG procedure of SAS estimates a scale parameter $\sigma$ and intercept $\mu$, where $\sigma=\gamma^{-1}$ and $\alpha=\exp (-\mu / \sigma)$. Under this parameterization, the hazard function decreases with age if $\sigma>1$. If $\sigma=1$, survival follows an exponential, constant hazard distribution.

When transmitters on day-old ducklings failed prematurely after having performed irregularly, and we had no indication that the duckling had died, we assumed the transmitter had failed. Such observations were treated as right-censored in the analysis; that is, we assumed the duckling survived until the transmitter failed.

When signals from some transmitters ended without indication of irregular performance (symptomless transmitter failures), we suspected that a predator destroyed the duckling and transmitter. Because we did not know this with certainty, we conducted one survival analysis for which such observations were treated as deaths and a second analysis for which they were treated as right-censored at last observation. For the Kaplan-Meier analysis we assumed that deaths occurred 12 hours after the last observation. For the Weibull model we assumed that deaths occurred sometime within the next 24 hours after the last observation (thus treating datum as interval-censored). If the time of release or rediscovery was not recorded in the data, we used 1430 hours, which was a typical time of day for those activities.

We first analyzed the data by considering mortality in total, regardless of the assigned 
Table 1. Fate of canvasback broods radiomarked at hatch at the Agassiz National Wildlife Refuge, 1987-90.

\begin{tabular}{lrrrrr}
\hline & 1987 & 1988 & 1989 & 1990 & Total \\
\hline Brood deployments $_{\text {Radiomarked ducklings }}{ }^{\mathrm{a}}$ & 5 & 11 & 23 & 13 & 52 \\
Brood losses $^{\mathrm{b}}$ & 22 & 43 & 96 & 56 & 217 \\
$\quad$ total & 2 & 4 & 5 & 7 & 18 \\
$\quad$ partial & 3 & 5 & 17 & 6 & 31 \\
$\quad$ none & 0 & 2 & 1 & 0 & 3 \\
\hline
\end{tabular}

a Deployed with radiotransmitters within 1 day of hatch.

${ }^{\mathrm{b}}$ Includes loss sustained during period of radiocontact with brood.

cause. This treatment permitted the most detailed examination of the data. We also performed some cause-specific analyses, for which we distinguished 4 mortality factors: predation, weather, disease, and inanition. We also identified a category of mortality, termed suspected predation, which included the losses from known predation and transmitter failures that were not preceded by abnormal transmissions. For the cause-specific analyses, we estimated mortality rates for each of the 5 factors as if it were the only source of mortality. Mortality from other sources was treated as right-censored at the time of death because it was not always possible to distinguish clearly among multiple causes of death. If the cause-specific factor contributed to mortality, we included that death in the analysis. For example, a duckling judged to have succumbed from predation and disease would be treated as a death in the analysis involving predation, a death in the analysis involving disease, but as a right-censored observation in the analyses involving weather or inanition.

Class-II ducklings.-We radiomarked 141 Class-II ducklings at an average estimated age of 37 days. Few of these ducklings died, and because we had no indication of an age-related hazard function, we analyzed data of Class-II ducklings with the Mayfield (1961) method, with standard errors that were determined according to Johnson (1979). Several transmitters failed without previously malfunctioning, and we again treated the data in 2 ways, first considering such observations as right-censored, and second considering them to be deaths.

\section{RESULTS}

During the 4-year study, 52 canvasback broods totaling 217 day-old, radiomarked ducklings were placed in nests and bonded with attendant hens within hours of hatch. Only 3 of 52 broods fledged without the death of 1 or more radiomarked ducklings, and 18 broods sustained total loss (Table 1).

\section{Causes of Mortality}

Day-old ducklings. - We recovered portions of 135 duckling carcasses during 1987-90. In many cases multiple factors contributed to the cause of mortality. Predation and weather-re-

Table 2. Contributing causes of death of canvasback ducklings radiomarked at hatch at the Agassiz National Wildlife Refuge, $1987-90^{\mathrm{a}}$.

\begin{tabular}{|c|c|c|c|c|c|c|c|}
\hline Year & $\operatorname{Sex}\left(n_{1}, n_{2}\right)^{\mathrm{b}}$ & $\begin{array}{c}\text { Known } \\
\text { predation }\end{array}$ & $\begin{array}{c}\text { Possible } \\
\text { predation }^{\mathrm{c}}\end{array}$ & Disease & Weather & Inanition & Unknown ${ }^{d}$ \\
\hline 1987 & Female $(8,0)$ & 7 & 7 & 0 & 0 & 0 & 1 \\
\hline \multirow[t]{2}{*}{1988} & Female $(13,2)$ & 5 & 7 & 1 & 4 & 1 & $\overline{4}$ \\
\hline & Male $(12,4)$ & 5 & 9 & 0 & 2 & 1 & 5 \\
\hline 1989 & Female $(33,11)$ & 16 & 27 & 1 & 11 & 2 & 6 \\
\hline \multirow[t]{2}{*}{1990} & Female $(26,3)$ & 19 & 22 & 3 & 2 & 1 & 3 \\
\hline & Male $(17,4)$ & 13 & 17 & 1 & 1 & 0 & 3 \\
\hline \multirow[t]{2}{*}{ All } & Female $(80,16)$ & 47 & 63 & 5 & 17 & 4 & 14 \\
\hline & Male $(55,28)$ & 33 & 61 & 1 & 10 & 4 & 11 \\
\hline
\end{tabular}

a Row sums may exceed the total number of mortalities for any year-sex class because some deaths have multiple causes of mortality.

b $n_{1}$ refers to number of recovered carcasses, $n_{2}$ refers to number of symptomless transmitter failures.

$\mathrm{c}$ Includes known predation and symptomless failure of transmitter.

d Cause of death could not be determined. 
Table 3. Number of canvasback ducklings killed by predators at the Agassiz National Wildlife Refuge, 1987-90.

\begin{tabular}{|c|c|c|c|c|c|}
\hline & 1987 & 1988 & 1989 & 1990 & Total \\
\hline \multicolumn{6}{|l|}{ Ducklings from hatch to 4 weeks of age } \\
\hline Mink & 11 & 5 & 9 & 15 & 40 \\
\hline Great horned owl (Bubo virginianus) & & 2 & 1 & 3 & 6 \\
\hline Black-crowned night-heron (Nycticorax nycticorax) & & & 1 & & 1 \\
\hline American coot (Fulica americana) & & 1 & & & 1 \\
\hline Other avian & & & 4 & 5 & 9 \\
\hline Snapping turtle (Chelydra serpentina) & & & & 1 & 1 \\
\hline Fox (Vulpes vulpes) & & & & 1 & 1 \\
\hline Unknown predator & & 2 & 8 & 7 & 17 \\
\hline Total depredations & 11 & 10 & 23 & 32 & 76 \\
\hline \multicolumn{6}{|l|}{ Ducklings $\geq 4$ weeks of age } \\
\hline Mink & & 1 & 1 & 3 & 5 \\
\hline Snapping turtle & & 1 & & & 1 \\
\hline Unknown predator & & 1 & & & 1 \\
\hline Total depredations & & 3 & 1 & 3 & 7 \\
\hline
\end{tabular}

lated factors were the major causes of mortality (Table 2). Among known mortalities, predation was the cause of $59 \%$ of female and $60 \%$ of male deaths. Mink were the single greatest cause of mortality (39-100\%) each year (Table 3). When suspected predation was included in the analysis, predation accounted for $66 \%$ of female and $73 \%$ of the male deaths.

Weather (exposure) was a contributing cause of mortality for 6 of the 22 assigned causes (27\%) in 1988 , and 18 of the 74 assigned causes $(24 \%)$ in 1989. Mortality often coincided with cold weather, especially when accompanied by precipitation, as in 1989 (Fig. 2). Cold weather with precipitation occurred on 6-8 June and on 1214 June, 1989, and consequently, among ducklings $<10$ days old, daily mortality rates were higher than the average rate of $0.08 \pm 0.12$. Exposure accounted for $53 \%$ of mortality during those periods (exposure mortality made up $37 \%$ of mortality that occurred outside of the 2 periods). Ducklings also died during less extreme conditions of cold temperature and precipitation (e.g., 21-22 Jun), but at lower rates.

Disease contributed to $6(4 \%)$ of the 135 deaths for which causes were assigned and inanition was involved in 8 (6\%) deaths. Bacterial pneumonia was the most common disease. Body mass at hatch was lower for individuals for which the principal cause of death was inanition (43.2 \pm $1.7 \mathrm{~g} ; n=7)$ than of surviving ducklings (46.3 $\pm 3.4 \mathrm{~g} ; n=80)(t=-4.16, P=0.002)$ and of individuals that died from other causes (45.6 \pm $3.6 \mathrm{~g} ; n=125)(t=-3.42, P=0.007)$.

Thirty-one ducklings were tested for pesticide exposure during 1988-90 (5 in 1988, 17 in 1989, and 9 in 1990). None exhibited clinical depression of brain acetylcholinesterase activity and we concluded that pesticide exposure probably was not a cause of mortality in canvasback ducklings at the Agassiz NWR.

Causes of mortality could not be determined for $25(19 \%)$ of the 135 recovered carcasses. A complete pathological evaluation was conducted on $68(50 \%)$ of the recovered ducklings. From this sample we identified 2 (3\%) ducklings for which the transmitter was a contributing or principal cause of mortality. We also found 7 (10\%) ducklings for which our pathological examination revealed minor effects related to the transmitter implant site.

Class-II ducklings.-Predation was the only known cause of death among the Class-II ducklings and all of these losses were among females. Mink were the single greatest cause of mortality (Table 3), as was the case with younger ducklings.

\section{Survival Analyses}

Day-old ducklings. - We first considered overall mortality, regardless of its cause. Parameter estimates from the Weibull model (Table 4) were used to produce survival curves (Fig. 1). The consistency of scale parameters exceeding 1 (Table 4), and the frequent significance of those departures, demonstrates the need for the Weibull model over the more parsimonious exponential model. There was a consistent pattern of higher survival rates for males than females in each year whether we censored symptomless transmitter failures or treated them as deaths (Table 5). Survival of males was higher 


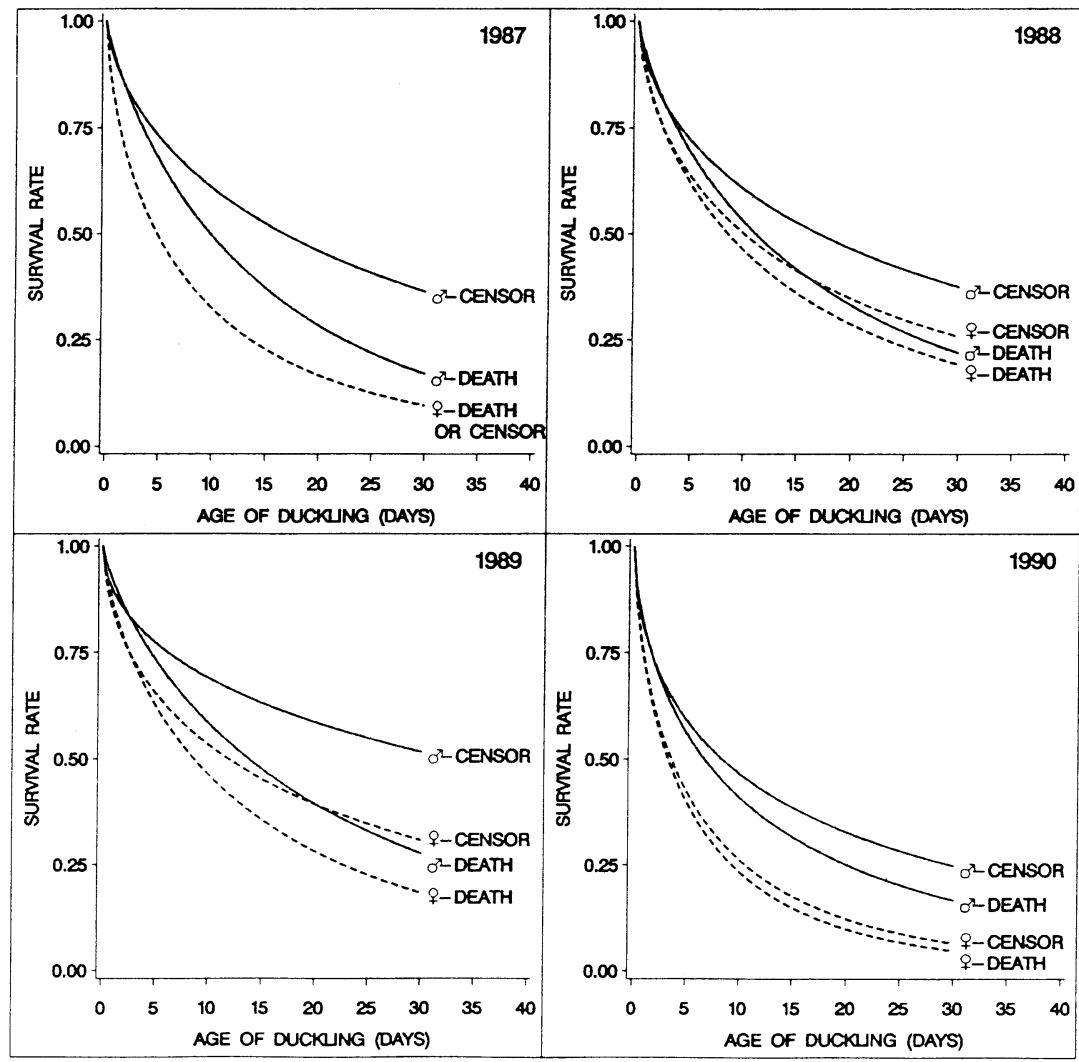

Fig. 1. Survival curves of radiomarked canvasback ducklings at the Agassiz National Wildlife Refuge, 1987-90. Curves labeled with CENSOR indicate survival values when symptomless transmitter failures were treated as censored and curves labeled with DEATH indicate survival values when symptomless transmitter failures were treated as deaths. Sample sizes were as follows: 1987, 10 females, 12 males; 1988, 20 females, 23 males; 1989, 52 females, 44 males; 1990, 33 females, 23 males.

(pooled estimate of the sex effect) when symptomless transmitter failures were treated as deaths $(P=0.03)$ and when symptomless transmitter failures were considered as censored $(P$ $=0.003)$. Male $(45.6 \pm 3.6[\mathrm{SD}] \mathrm{g} ; n=104)$ and female $(46.0 \pm 3.5 \mathrm{~g} ; n=113)$ ducklings did not differ in body mass at hatch $(t=0.74, P=$ $0.46)$. Duckling body mass differed among years $(43.9 \pm 3.2 \mathrm{~g}$ in 1990 versus $46.9 \pm 3.9 \mathrm{~g}$ in 1987; $F=9.03 ; 3,215 \mathrm{df} ; P<0.0001$ ).

We estimated survival curves for each sex and year, assuming in turn that each of the 5 mortality factors was the only cause of death. As expected, cause-specific survival rates were high except for predation and, in 1988 and 1989, for weather. For example, estimated survival to 20 days of age, averaged across all sex and year groups, was 0.522 for known predation, 0.395 for known or suspected predation, 0.871 for weather, 0.956 for inanition, and 0.959 for disease.
Class-II ducklings. - Only 7 deaths were observed during 3366.5 cumulative exposure-days of observation of 73 female and 68 male ducklings (Table 6). When symptomless transmitter failures were included as deaths, the disparity between the sexes diminished, with 27 female and 16 male mortalities. When symptomless transmitter failures were treated as censored, daily survival rates pooled across years were 0.996 for females and 1.0 for males; when symptomless transmitter failures were treated as deaths, daily survival rates pooled across years were 0.985 for females and 0.990 for males. These values correspond to survival rates for a 26-day period (from an average age of 37 days when radiomarked to fledging at 63 days) of 0.91 for females and 1.0 for males when symptomless transmitter failures were treated as censored, and 0.71 for females and 0.79 for males when symptomless transmitter failures were treated as deaths. 


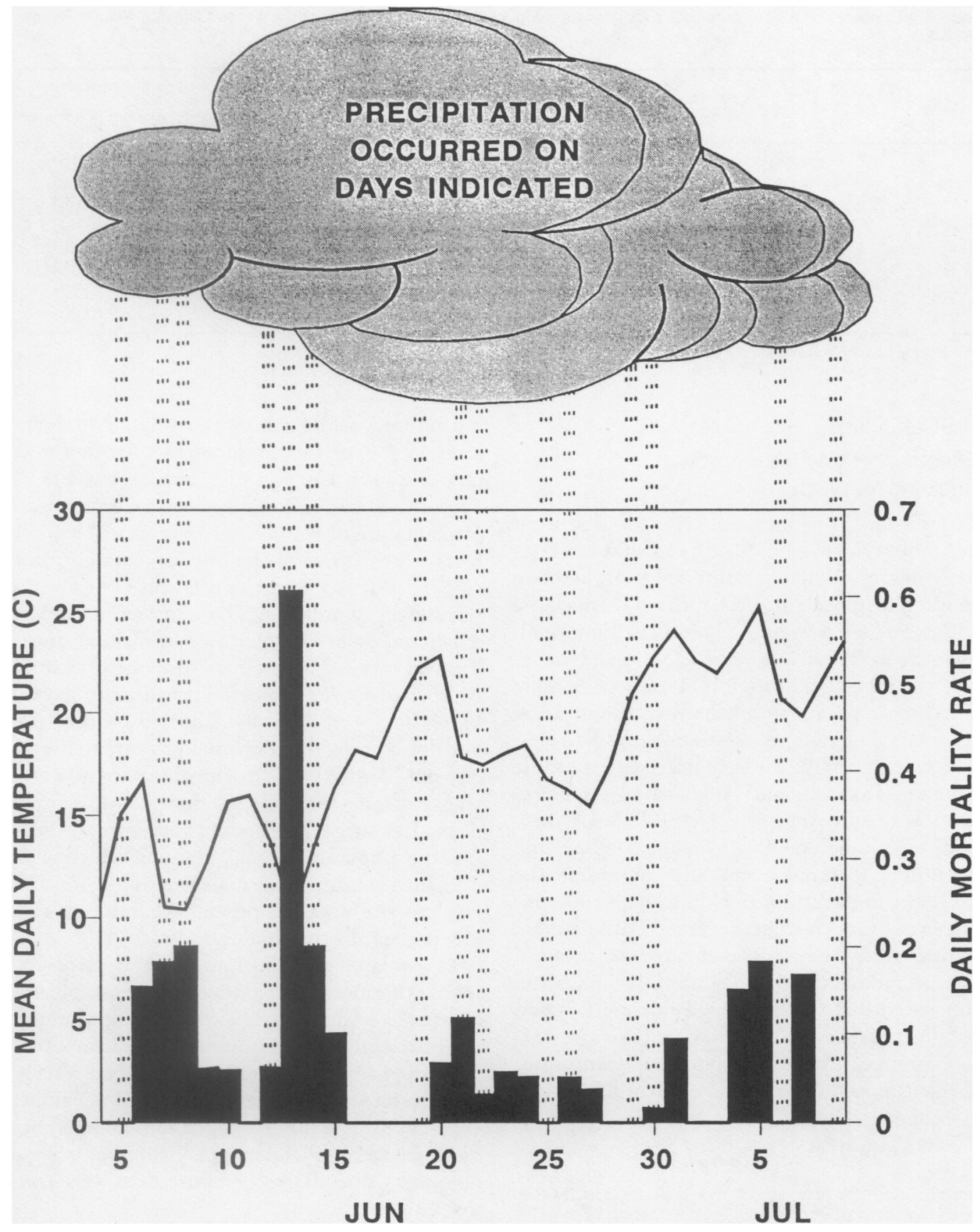

Fig. 2. Relation of canvasback duckling mortalities with weather patterns at the Agassiz National Wildlife Refuge, 1989. The solid line depicts daily mean temperatures. Shading extends below cloud on days with precipitation. Daily mortality rates of canvasback ducklings are represented by solid bars. 
Table 4. Estimates of Weibull parameters for canvasback ducklings by sex and year at the Agassiz National Wildlife Refuge, 1987-90.

\begin{tabular}{cllcccc}
\hline & & \multicolumn{2}{c}{$\begin{array}{c}\text { Symptomless transmitter failures treated } \\
\text { as deaths }\end{array}$} & & \multicolumn{2}{c}{$\begin{array}{c}\text { Symptomless transmitter failures treated } \\
\text { as censored }\end{array}$} \\
\cline { 3 - 4 } \cline { 6 - 6 } Year & Sex & Intercept & Scale & & Intercept & Scale \\
\hline 1987 & Female & $2.12(0.67)^{\mathrm{a}}$ & $1.50(0.53)$ & & $2.12(0.67)$ & $1.50(0.53)$ \\
& Male & $2.72(0.49)$ & $1.19(0.41)$ & & $3.38(0.87)$ & $1.54(0.67)$ \\
1988 & Female & $2.67(0.38)$ & $1.46(0.32)$ & & $2.90(0.46)$ & $1.64(0.39)$ \\
& Male & $2.87(0.33)$ & $1.27(0.28)$ & & $3.43(0.54)$ & $1.64(0.44)$ \\
1989 & Female & $2.67(0.21)$ & $1.39(0.17)$ & & $3.12(0.31)$ & $1.75(0.26)$ \\
& Male & $3.09(0.21)$ & $1.26(0.17)$ & & $4.20(0.48)$ & $1.91(0.37)$ \\
& Female & $1.75(0.28)$ & $1.49(0.20)$ & & $1.86(0.29)$ & $1.54(0.22)$ \\
& Male & $2.49(0.35)$ & $1.57(0.27)$ & & $2.80(0.44)$ & $1.82(0.36)$ \\
\hline
\end{tabular}

a Values in parentheses are standard errors.

\section{DISCUSSION}

\section{Effects of Radiomarking on Duckling Survival}

Radiomarking and duckling deployment techniques developed during this study provided estimates of duckling survival from hatch to fledging without the bias typically associated with visually determining brood attrition. Analysis of video-taped interactions between females and ducklings indicated that radio packages posed no apparent problems with the females' acceptance of radiomarked ducklings.

Krementz and Pendleton (1991) used the same technique to radiomark mallard (Anas platyrhynchos) and American black duck (A. rubripes) ducklings on the Chesapeake Bay and were able to more accurately determine the causes of mortality in ducklings with radioimplants than for ducklings marked with external transmitters. They also compared observation rates of radiomarked and control ducklings and concluded that the implanted transmitters had no effect on survival.

The effect of our subcutaneous transmitter implant procedure on the growth and behavior of redhead ducklings was evaluated by com-

Table 5. Coefficients for sex effect in Weibull model, by year, for canvasback ducklings at the Agassiz National Wildlife Refuge, 1987-90.

\begin{tabular}{cccccc}
\hline & \multicolumn{2}{c}{$\begin{array}{c}\text { Symptomless transmitter } \\
\text { failures treated } \\
\text { as deaths }\end{array}$} & & \multicolumn{2}{c}{$\begin{array}{c}\text { Symptomless transmitter } \\
\text { failures treated } \\
\text { as censored }\end{array}$} \\
\cline { 2 - 3 } \cline { 5 - 6 } Year & Coefficient & $P$-value & & Coefficient & $P$-value \\
\hline 1987 & 0.61 & 0.46 & & 1.24 & 0.23 \\
1988 & 0.21 & 0.67 & & 0.53 & 0.44 \\
1989 & 0.40 & 0.18 & & 1.00 & 0.05 \\
1990 & 0.77 & 0.07 & & 0.98 & 0.05 \\
\hline
\end{tabular}

paring control and transmitter-implanted ducklings in 2 experiments (ducklings treated at 1 day of age in 1 experiment and at 4 weeks of age in the other) (Zenitsky 1993). Surgery and implantation of transmitters had short-term effects on growth, most obvious immediately after surgery, but treatment effects were not always statistically significant. The effect of an apparent initial delay in growth of implanted ducklings on survival is unknown, because ducklings compensated with increased growth rate shortly thereafter. Activities of control ducklings did not differ from those of ducklings treated at 1 day old (Zenitsky 1993). Ducklings treated at 4 weeks of age foraged less than controls for 2 days after surgery, spending more time preening the implant site and antenna. By day 2, ducklings resumed normal foraging rates and implant site/antenna preening continued at a low percent of the time sampled.

In a related study, an assessment of the potential thermoregulatory energetic costs of subcutaneous radioimplants to ducklings, under various degrees of thermal stress, indicated that the presence of a radiotransmitter had no significant effect on net heat production (Bakken et al. 1996). The results suggested that ducklings radiomarked with subcutaneous implants were no more vulnerable to exposure than were control birds.

We also conducted pathological examinations on 68 ( $50 \%$ of all ducklings, but $56 \%$ of ducklings during 1988-90) ducklings that died during the study. Only 2 of these birds had sufficient pathological findings associated with the transmitter implant or surgical procedure to influence the birds' survival. Both of these birds died within 2 days of the transmitter implant. In addition, 7 duckling carcasses had minor necrosis or in- 
Table 6. Mortality and estimated daily survival rates $\left(\hat{S}^{\prime}\right)$ of Class-ll canvasback ducklings at the Agassiz National Wildlife Refuge, 1987-90.

\begin{tabular}{|c|c|c|c|c|c|c|c|c|c|}
\hline \multirow[b]{2}{*}{ Year } & \multirow[b]{2}{*}{ Sex } & \multirow[b]{2}{*}{$n$} & \multirow{2}{*}{$\begin{array}{c}\text { Days of } \\
\text { exposure }\end{array}$} & \multicolumn{3}{|c|}{$\begin{array}{l}\text { Symptomless transmitter failures } \\
\text { treated as deaths }\end{array}$} & \multicolumn{3}{|c|}{$\begin{array}{l}\text { Symptomless transmitter failures } \\
\text { treated as censored }\end{array}$} \\
\hline & & & & Deaths & $\hat{\mathbf{S}}$ & $\mathrm{SE}$ & Deaths & $\overline{\mathbf{S}}$ & $\overline{S E}$ \\
\hline \multirow[t]{2}{*}{1987} & Female & 15 & 210.0 & 6 & 0.971 & 0.011 & 0 & 1.000 & 0.000 \\
\hline & Male & 8 & 152.0 & 3 & 0.980 & 0.011 & 0 & 1.000 & 0.000 \\
\hline \multirow[t]{2}{*}{1988} & Female & 16 & 430.0 & 4 & 0.991 & 0.005 & 3 & 0.993 & 0.004 \\
\hline & Male & 20 & 467.0 & 1 & 0.998 & 0.002 & 0 & 1.000 & 0.000 \\
\hline \multirow[t]{2}{*}{1989} & Female & 25 & 805.0 & 8 & 0.990 & 0.003 & 1 & 0.999 & 0.001 \\
\hline & Male & 28 & 719.0 & 6 & 0.992 & 0.003 & 0 & 1.000 & 0.000 \\
\hline \multirow[t]{2}{*}{1990} & Female & 17 & 307.5 & 9 & 0.971 & 0.010 & 3 & 0.990 & 0.006 \\
\hline & Male & 12 & 276.0 & 6 & 0.978 & 0.009 & 0 & 1.000 & 0.000 \\
\hline \multirow[t]{2}{*}{ All } & Female & 73 & $1,752.5$ & 27 & 0.985 & 0.003 & 7 & 0.996 & 0.002 \\
\hline & Male & 68 & $1,614.0$ & 16 & 0.990 & 0.002 & 0 & 1.000 & 0.000 \\
\hline
\end{tabular}

${ }^{1}$ Survival rate calculated with the Mayfield (1961) method, with standard errors determined according to Johnson (1979).

flammation at the transmitter site. These incidental effects ranged from inflammation caused by bacterial infection to skin and muscle necrosis at the transmitter site, but were not considered to be a direct contributor to the bird's mortality.

We suspect that most methods of marking waterfowl with radiotransmitters influence survival rates to some degree (Wheeler 1991, Ward and Flint 1995). Assuming that we conducted pathological examinations on a representative sample of ducklings that died, we believe that our estimated survival rates may be biased low because the radioimplant technique probably contributed to the death of a few birds. Our pathology data suggests that about $3 \%$ (95\% CI $=0.4-10 \%$ ) of the estimated mortality may be a result of the transmitter implant. However, radiotelemetry is the only reliable method available that provides information to determine accurately the time of death, location of carcasses, causes of mortality, detailed field evidence of habitat used, and detailed movements of individuals relative to one another (e.g., brood behavior) of highly secretive and cryptic animals such as ducklings.

\section{Timing of Mortality}

Risk of mortality for canvasback ducklings at the Agassiz NWR decreased through the period from hatch to fledging (Fig. 1). Mortality was greatest during the first 10 days; 10 -day survival rates varied from a low of 0.26 in females in 1990 to a high of 0.69 in males in 1989. This pattern of mortality is consistent with that reported for canvasback (Leonard 1990) and other species: wood duck (Aix sponsa) (McGilvrey
1969), American black duck (Reed 1975, Ringelman and Longcore 1982), ring-necked duck (Aythya collaris) (McAuley and Longcore 1988), and mallard (Orthmeyer and Ball 1990).

\section{Causes of Duckling Mortality}

Causes of canvasback duckling mortality were consistent with that reported for other species and included predation (Sargeant and Raveling 1992), adverse weather conditions, inanition, and disease (Table 2). Adverse weather events marked by cold temperatures, precipitation, and wind, or prolonged periods of mild cold stress may affect ducklings both directly (hypothermia) or indirectly (Johnson et al. 1992). Such conditions predispose ducklings to other causes of mortality through increased rate of energy loss, changes in activity, reduced growth rate, or reduced food availability. On the other hand, disturbance from predation may predispose ducklings to cold stress. The brood histories and movements in this study revealed that some encounters with predators scattered broods, resulting in exposure deaths of ducklings no longer tended by hens. Vulnerability to predators, inclement weather, and starvation are probably affected by the quality of wetland habitat in which the broods reside.

Ducklings that died with signs of inanition had a mean body mass of $3.2 \mathrm{~g}$ less at hatch than ducklings that survived. Inanition also occurs in domestic poultry neonates (3-7 days) that never begin to eat and therefore starve to death after their yolks are depleted (Langenberg and Montali 1983). Inanition in wild ducklings may be complicated by cold weather and lack of food. Untergasser and Hayward (1972) 
reported that body weight in 3 species of ducklings increased little, or not at all, during a period of a few cold and rainy days. The availability of invertebrates (e.g., chironomids hatching) may also be depressed during periods of adverse weather to further reduce food intake. This type of mortality may be reduced through improvement in the quality and quantity of brood-rearing habitats. In any event, ducklings suffering from inanition-related problems are probably at higher risk of mortality both from predators and exposure. Johnson et al. (1992) referenced several studies that suggested starvation as a probable major cause of mortality among young waterfowl.

Disease mortality may also be difficult to document in young birds because generally they have an undeveloped immune system, may be highly susceptible to infectious agents (which are difficult to detect), and are subject to greater risk from predation than healthy individuals. Bacterial pneumonia was the most common cause of disease mortality among canvasback ducklings. However, this source of disease mortality was never as prevalent in canvasback ducklings as in mallards on the Chesapeake Bay (Krementz and Pendleton 1991), where during 1 year of the study, $43 \%$ of radiomarked ducklings died of pneumonia.

\section{Differential Survival Between Male and Female Ducklings}

Estimated survival rates for prefledged ducklings at the Agassiz NWR were lower for females than for males. The cause of this disparity is unknown and we can only speculate on the implications of this finding. Differential survival rates were not related to duckling size at hatch, and duckling growth curves have been shown to be similar for male and females during the first month of life (Dzubin 1959), the time when most mortality occurs.

Sex-related differences in survival of precocial young have been observed among some species under conditions of decreased food availability. Juvenile male sage grouse (Centrocercus urophasianus) suffered greater mortality than did juvenile females during periods of food shortage and in poorer habitats (Swenson 1986). Latham (1947) believed a physiological difference between sexes was responsible for observed differential tolerance to extremes of climate and starvation in ring-necked pheasant (Phasianus colchicus) chicks for which, except for trials involving chicks $<3$ days old, females survived at higher rates than males.
Studies of duckling survival in the wild have not involved birds of known sex. However, among artificially incubated canvasbacks, Hochbaum (1944) reported a slightly higher embryonic mortality rate for females. Kear (1965) also observed a higher mortality rate for female than male mallard ducklings; most mortality occurred at hatching.

\section{MANAGEMENT IMPLICATIONS}

Predation and weather played key roles in the mortality of canvasback ducklings. The loss of ducklings to mink, other predators, and exposure may be influenced by the quality of aquatic habitat and weather conditions during the first few weeks after hatch. Management of large impoundments, such as those at the Agassiz NWR, can mediate these effects by providing optimal water levels for (1) establishment of brood cover, (2) production of invertebrate foods, (3) protection from predatory mammals, and (4) creation of a large volume of water as a thermal mass to buffer temperature extremes. The behavioral and physiological basis of lower survival of female canvasback ducklings found in this study is not understood and needs further examination. Future research should be directed to identify factors that lead to differential survival rates at this early age, and to determine the influence of radiomarking techniques on survival.

\section{LITERATURE CITED}

Anderson, M. G., R. D. Sayler, and A. D. Afton. 1980. A decoy trap for diving ducks. J. Wildl. Manage. 44:217-219.

BakKen, G. S., P. S. Reynolds, K. P. Kenow, C. E. KORSCHGEN, AND A. F. BOYSEN. 1996. Thermoregulatory effects of radiotelemetry transmitters on mallard ducklings. J. Wildl. Manage. 60: In Press.

Ball, I. J., D. S. Gilmer, L. M. Cowardin, AND J. H. RiechmanN. 1975. Survival of wood duck and mallard broods in north-central Minnesota. J. Wildl. Manage. 39:776-780.

Canadian Wildlife Service, and U.S. Fish aNd WILDLIFE SERVICE. 1994. Waterfowl population status, 1994. U.S. Fish and Wildl. Serv., Washington, D.C.; Environ. Canada, Can. Wildl. Serv., Ottawa, Ontario. 39pp.

Cowardin, L. M., V. Carter, F. C. Golet, and E. T. LAROE. 1979. Classification of wetlands and deepwater habitats of the United States. U.S. Fish and Wildl. Serv. Biol. Serv. Program, Washington, D.C. 103 pp.

- AND D. H. Johnson. 1979. Mathematics and mallard management. J. Wildl. Manage. 43: 18-35.

, D. S. Gilmer, AND C. W. Shaiffer. 1985. Mallard recruitment in the agricultural environment of North Dakota. Wildl. Monogr. 92. 
Cummings, G., AND O. HewitT. 1964. Capturing waterfowl and marsh birds at night with light and sound. J. Wildl. Manage. 28:120-126.

Dodge, W. E., AND A. J. Steiner. 1986. XYLOG: A computer program for field processing locations of radio-tagged wildlife. U.S. Fish and Wildl. Serv., Fish Wildl. Tech. Rep. 4. 22pp.

Doty, H. A. 1972. Hatchability tests with eggs from captive wood ducks. Poult. Sci. 51:849-853.

Dzubin, A. 1959. Growth and plumage development of wild-trapped juvenile canvasback (Aythya valisineria). J. Wildl. Manage. 23:279-290.

GoldberG, D. R., M. D. Samuel, C. B. Thomas, P. Sharp, G. L. KrapU, J. R. RobB, K. P. Kenow, C. E. KorsChgEN, W. H. ChIPLEY, M. J. CONROY, AND S. H. KLEVEN. 1995. The occurrence of mycoplasmas in selected wild North American waterfowl. J. Wildl. Dis. 31:364-371.

Haramis, G. M., E. L. Derleth, and D. G. MCAULEY. 1987. A quick-catch corral trap for wintering canvasbacks. J. Field Ornithol. 58:198200.

HILL, E. F. 1988. Brain cholinesterase activity of apparently normal wild birds. J. Wildl. Dis. 24: 51-61.

Hochbaum, H. A. 1944. The canvasback on a prairie marsh. Am. Wildl. Inst., Washington, D.C.

JOHNSON, D. H. 1979. Estimating nest success: the Mayfield method and an alternative. Auk 96: 651-661.

- J. D. Nichols, AND M. D. SChWARTZ. 1992. Population dynamics of breeding waterfowl. Pages 446-485 in B. D. J. Batt, A. D. Afton, M. G. Anderson, C. D. Ankney, D. H. Johnson, J. A. Kadlec, and G. L. Krapu, eds. Ecology and management of breeding waterfowl. Univ. Minn. Press, Minneapolis.

Kaplan, E. L., AND P. MEIER. 1958. Nonparametric estimation from incomplete observations. J Am. Statist. Assoc. 53:457-481.

KEAR, J. 1965. The internal food reserves of hatching mallard ducklings. J. Wildl. Manage. 29:523528 .

KLein, J. P., AND M. L. MoesChberger. 1989. The robustness of several estimators of the survivorship function with randomly censored data. Commun. Statist. Simula. 18:1087-1112.

Korschgen, C. E., S. J. Maxson, and V. B. Kuechle. 1984. Evaluation of implanted radio transmitters in ducks. J. Wildl. Manage. 48:982-987.

- K. P. KenOW, W. L. GReEN, M. D. SAMUEL, AND L. SILEO. 1996. Technique for implanting radio transmitters subcutaneously in day-old ducklings. J. Field Ornithol. 67: In Press.

Krementz, D. G., and G. W. Pendleton. 1991. Movements and survival of American black duck and mallard broods on Chesapeake Bay. Proc. Annu. Conf. Southeast. Assoc. Fish and Wildl. Agencies 45:156-166.

LANGENBERG, J., AND R. J. Montali. 1983. Avian neonatal pathology. Annu. Proc. Am. Assoc. Zoo Vet. 1983:172-175.

LAtham, R. M. 1947. Differential ability of male and female game birds to withstand starvation and climatic extremes. J. Wildl. Manage. 11:139149.

LEONARD, J. P. 1990. Survival and movements of canvasback ducklings-impact of brood density.
M. S. Thesis, Michigan State Univ., East Lansing. $49 \mathrm{pp}$.

MAYFIELD, H. 1961. Nesting success calculated from exposure. Wilson Bull. 73:255-261.

MCAULEY, D. G., AND J. R. LONGCORE. 1988. Survival of ring-necked ducks on wetlands of different $\mathrm{pH}$. J. Wildl. Manage. 52:169-176.

MCGilvrey, F. B. 1969. Survival in wood duck broods. J. Wildl. Manage. 33:73-76.

MilLER, R. G., JR. 1983. What price Kaplan-Meier? Biometrics 39:1077-1081.

Olsen, G. H., F. J. Dein, G. M. Haramis, and D. G. JORDE. 1992. Implanting radio transmitters in wintering canvasbacks. J. Wildl. Manage. 56: 325-328.

OrThMEYER, D. L., AND I. J. BALl. 1990. Survival of mallard broods on Benton Lake National Wildlife Refuge in northcentral Montana. J. Wildl. Manage. 54:62-66.

Pollock, K. H., S. R. Winterstein, C. M. BunCK, AND P. D. CURTIS. 1989. Survival analysis in telemetry studies: the staggered entry design. J. Wildl. Manage. 53:7-15.

REED, A. 1975. Reproductive output of black ducks in the St. Lawrence Estuary. J. Wildl. Manage. 39:243-255.

RINGELMAN, J. K., AND J. R. LONGCORE. 1982. Survival of juvenile black ducks during broodrearing. J. Wildl. Manage. 46:622-628.

RoCKE, T. E., AND M. D. SAMUEL. 1991. Brain acetylcholinesterase activity in botulism-intoxicated mallards. J. Wildl. Dis. 27:317-319.

SAS INSTITUTE INC. 1989. SAS/STAT user's guide, version 6 , fourth edition. SAS Institute, Inc., Cary, N.C

Sargeant, A. B., and D. G. Raveling. 1992. Mortality during the breeding season. Pages 396-422 in B. D. J. Batt, A. D. Afton, M. G. Anderson, C. D. Ankney, D. H. Johnson, J. A. Kadlec, and G. L. Krapu, eds. Ecology and management of breeding waterfowl. Univ. Minn. Press, Minneapolis.

STOUDT, J. H. 1982. Habitat use and productivity of canvasbacks in southwestern Manitoba, 196172. U.S. Fish and Wildl. Serv. Spec. Sci. Rep. Wildl. No. 248. 31 pp

Swenson, J. E. 1986 . Differential survival by sex in juvenile sage grouse and gray partridge. Ornis Scand. 17:14-17.

TALENT, L. G., R. L. JaRVIS, AND G. L. KRAPU. 1983. Survival of mallard broods in south-central North Dakota. Condor 85:74-78.

U.S. Fish aNd Wildlife SERvice, and CaNadiaN WILDLIFE SERVICE. 1986. North American waterfowl management plan: a strategy for cooperation. U.S. Fish and Wildl. Serv., Washington, D.C.; Environ. Canada, Can. Wildl. Serv., Ottawa, Ontario. 19 pp.

UNTERgasser, G., AND J. S. Hayward. 1972 . Development of thermoregulation in ducklings. Can J. Zool. 50:1243-1250.

WARD, D. H., AND P. L. Flint. 1995. Effects of harness-attached transmitters on premigration and reproduction of brant. J. Wildl. Manage. 59 39-46.

WELLER, M. W. 1957. Growth, weights, and plumages of the redhead, Aythya americana. Wilson Bull. 69:5-38. 
WHEELER, W. E. 1991. Suture and glue attachment of radio transmitters on ducks. J. Field Ornithol. 62:271-278.

ZENITSKY, G. D. 1993. Growth and behavior of redhead ducklings implanted with dummy radio transmitters. M. S. Thesis, Iowa State Univ., Ames. 156pp.

Received 24 June 1994

Accepted 15 August 1995.

Associate Editor: Conroy. 